DEMOGRAPHIC RESEARCH

VOLUME 37, ARTICLE 53, PAGES 1707-1734

PUBLISHED 6 DECEMBER 2017

http://www.demographic-research.org/Volumes/Vol37/53/

DOI: 10.4054/DemRes.2017.37.53

Research Article

\title{
Acculturation style, transnational behaviour, and return-migration intentions of the Turkish second generation: Exploring linkages
}

\section{George Groenewold}

\section{Helga A.G. de Valk}

(C) 2017 George Groenewold \& Helga A.G. de Valk.

This open-access work is published under the terms of the Creative Commons Attribution 3.0 Germany (CC BY 3.0 DE), which permits use, reproduction, and distribution in any medium, provided the original author(s) and source are given credit.

See https://creativecommons.org/licenses/by/3.0/de/legalcode. 


\section{Contents}

1 Introduction 1708

$2 \quad$ Conceptualization and expectations 1710

2.1 Acculturation style, transnational behaviour, and return migration 1710

$\begin{array}{ll}2.2 \text { Linkages, determinants, and expectations } & 1711\end{array}$

3 Data 1715

$4 \quad$ Methods and variables 1716

$5 \quad$ Results 1719

5.1 Characteristics of the Turkish second generation 1719

5.2 Linkages between acculturation style, transnational behaviour, 1720

$\begin{array}{lll}6 & \text { Discussion } & 1725\end{array}$

$\begin{array}{lll}7 & \text { Acknowledgements } & 1727\end{array}$

$\begin{array}{ll}\text { References } & 1728\end{array}$ 


\title{
Acculturation style, transnational behaviour, and return-migration intentions of the Turkish second generation: Exploring linkages
}

\author{
George Groenewold ${ }^{1}$ \\ Helga A.G. de Valk $^{2}$
}

\begin{abstract}
BACKGROUND

In public discourse, acculturation, transnational behaviour, and migration are highly debated and viewed as related. In the academic literature, this relationship has hardly received attention. This article explores linkages between these processes and how they are determined by indicators of cultural distance (i.e., perceived discrimination and religiosity) and personality (i.e., self-efficacy).
\end{abstract}

\section{METHOD}

We derive a general theoretical model for these processes and determinants and test it by using structural equation modelling on the TIES survey data of the Turkish second generation in six European countries.

\section{RESULTS}

Model-fit statistics indicate that our theoretical model is supported by the survey data of the six countries and by pooled-country data. We found that the type of acculturation style preferred by the Turkish second generation influences how transnationally active they are and what their migration intentions are. We also found that being more transnationally active correlates with a stronger intention to migrate to Turkey. Cultural distance (religiosity and perceived discrimination) and, less so, personality traits (selfefficacy) impinge on these relationships.

\section{CONTRIBUTION}

Our theoretical model helps to explain how acculturation, transnational behaviour, and migration intentions are related to and determined by cultural distance and personality traits. Country-specific configurations of the model exist and underscore the importance of taking characteristics of the country context into account when studying the behaviour of immigrant groups. Furthermore, the TIES project collected unique, rich,

\footnotetext{
${ }^{1}$ Netherlands Interdisciplinary Demographic Institute/KNAW/University of Groningen, Population Research Center. E-Mail: groenewold@nidi.nl.

${ }^{2}$ Netherlands Interdisciplinary Demographic Institute/KNAW/University of Groningen, Population Research Center.
} 
and comparable data that is available to the research community for studying the lives of the Turkish second generation from an international comparative perspective.

\section{Introduction}

In public discourse, acculturation style, transnational behaviour, and migration are highly debated and viewed as related. The term 'acculturation style' refers to the routine behaviour of people of immigrant origin regarding whether to act based on their own ethnic group norms, values, and customs or on those of the national majority population in the country to which they immigrated (e.g., Bean et al. 2010; Berry 1997). The term 'transnational behaviour' refers to the involvement of immigrants in the social, cultural, or economic activities of the countries from which they emigrated (e.g., Levitt 2009; Levitt and Jaworsky 2007; Wessendorf 2013). In the academic literature, however, the interrelatedness of these processes is rarely addressed explicitly or studied empirically. Traditional models of migration generally do not address aspects of acculturation and transnational behaviour (Berry 1990; Castles, de Haas, and Miller 2014; Haug 2008; Massey et al. 1999; Schiller, Basch, and Blanc-Szanton 1992). In more recent work, these aspects receive more attention but are not yet fully explored (e.g., Crul and Schneider 2010; de Haas 2010; Snel, Engbersen, and Leerkes 2006).

In this article, we study the interrelatedness and determinants of acculturation and transnational behaviour and link these factors to return-migration intentions. We do so from the perspective of the Turkish immigrant community in Europe. Our focus is on young adults of Turkish parentage who were born and raised and reside in a European country. We refer to these people as the Turkish second generation. These people have come of age and have become sizeable urban subpopulations, but knowledge of their attitudes, preferences, and behaviour is still rather limited (Crul, Schneider, and Lelie 2012).

The Turkish second generation is exposed to norms and value systems that are different from, and sometimes in conflict with, the norms and value systems of their parents. Immigrant parents often transfer traditional Turkish norms, values, and customs to their children, but while the children are in school or at work, they learn about the norms and values of the mainstream society of the European country where they grow up and live. Through periodic contact with relatives in Turkey and exposure to the Turkish media, they are exposed to contemporary Turkish norms, values, and customs. This exposure may result in acculturative stress, formation of multiple identities, and conflicting loyalties (e.g., Alba and Nee 2003; Bean et al. 2010; Becker 2010; Crul, Schneider, and Lelie 2012). During the life course, second-generation Turks 
have to come to grips with these different norms and value systems, and this process leads to particular acculturation styles (e.g., Berry et al. 1987; Berry et al. 2006; Berry and Sabatier 2010; Berry, Trimble, and Olmeda 1986).

Having parents of migrant origin often fosters transnational behaviour because the second generation is raised and socialized in a context where relatives in the parents' country of origin often play an important role. When becoming young adults, the second generation may choose to expand and intensify contact and activities with those people (Schiller, Basch, and Blanc-Szanton 1992). Depending on cultural preferences, transnational activities and ties, and other factors, such as living conditions, the second generation may even consider 'returning' to the parents' country of origin. In the literature (e.g., Christou and King 2015; King and Kilinc 2013; Wessendorf 2013), this process is called roots-migration or counter-diasporic migration.

Relationships between acculturation style, transnational behaviour, and return migration are affected by other factors too, such as cultural distance and personality traits (e.g., Aleksynska and Chiswick 2011; de Jong 1994, 2000). On the one hand, cultural distance can be viewed from the perspective of objective differences between members of immigrant groups and majority populations, such as differences in religion and religiosity. Turkish young adults mainly adhere to Islam and are generally more religious than Christian European majority populations, who are generally less religious (e.g., Gallup International 2012; Pew Research Center 2005). This adherence to Islam may lead to different behaviour in certain life domains, such as in family formation and intermarriage, and (female) labour force participation and career expectations (Harris 1994; Huschek, de Valk, and Liefbroer 2012; Idema and Phalet 2007). On the other hand, cultural distance can be viewed from the perspective of the majority population in terms of acts of discrimination, social exclusion, and negative stereotyping. People respond to and cope with cultural distance in different ways because people have different personality traits, such as efficacy to deal with challenging situations (Bandura 2001).

The objective of this article is to explore how acculturation style, transnational behaviour, and return migration are related, and how indicators of cultural distance and personality impinge on those relations. More specifically, we are interested in examining the extent to which acculturation style mediates effects that cultural distance and personality have on transnational behaviour and return-migration intentions. To do so, we develop a theoretical model and use multi-country survey data of Turkish second-generation respondents in six European countries to empirically test the model. 


\section{Conceptualization and expectations}

\subsection{Acculturation style, transnational behaviour, and return migration}

Acculturation styles have been addressed by several authors in the scientific literature, including Berry et al. (2006), Berry and Sabatier (2010), Bourhis et al. (1997) and Navas et al. (2007). They all argue that contact between national majority populations and immigrant groups leads to adaptations in the cultural value systems of both groups. To guide behaviour in different domains of life, people of immigrant origin develop routines regarding whether to act based on their own ethnic group norms, values, and customs or on those of the national majority population. Based on this duality, Berry, Trimble, and Olmeda (1986) derived a typology composed of four acculturation styles: assimilation, integration, separation, and marginalization (Dona and Berry 1994). People with an assimilation style act mainly in accordance with the national majority population's value system. People with an integration style try to abide by the value system of the national majority population as well as that of the immigrant group. People with a separation style refer most to the value system of their immigrant group, while people who do not hold preferences for any particular value system are classified as preferring a marginalization style. In our study, we follow Berry, Trimble, and Olmeda (1986) in that we interpret acculturation as a two-dimensional concept. The implication is that acculturation style, in our study, is represented by its two dimensions: (1) preference for the majority population's national society value system and (2) preference for the immigrant group (i.e., Turkish) value system, referred to as NSP and IGP, respectively (Groenewold, de Valk, and Van Ginneken 2014).

The concept of transnationalism was introduced by social anthropologists (e.g., Schiller, Basch, and Blanc-Szanton 1992) in the 1990s after it became clear that most first-generation immigrants in Western countries did not return and, instead, developed a lifestyle in which the people and the social, cultural, and economic activities in their countries of origin and destination became intertwined (e.g., Levitt 2009; Levitt and Jaworsky 2007). Over time, transnational behaviour and lifestyle were furthered by decreases in travel and communication costs and by access to the internet and social media. Furthermore, during their upbringing, the second generation benefited from parental cross-border social fields in that they 'inherited' social capital in the parents' country of origin, contributing to a transnational lifestyle. Depending on circumstances, such a lifestyle may foster return-migration intentions (e.g., Nahapiet and Ghoshal 1998: 243; Portes and Rumbaut 2001; Wessendorf 2013).

In the literature, transnational behaviour is commonly viewed as an alternative to return migration (Levitt 2009; Levitt and Jaworsky 2007). For instance, first-generation immigrants may not have the resources and support to return, or political conditions 
prevent them to return, such as in the case of refugees (e.g., Turkish-Kurds). A transnational lifestyle may also be viewed as an optimal lifestyle (de Haas 2010). Conversely, a transnational lifestyle may be viewed as a preparatory stage of return migration, in particular if living conditions in Turkey became more attractive in terms of welfare growth, and if xenophobia, discrimination, and unemployment increase in European countries (e.g., Haug 2008; King and Kilinc 2013; Wessendorf 2013).

\subsection{Linkages, determinants, and expectations}

Linkages between acculturation, transnational behaviour, and migration have only recently been addressed in migration studies, and only to a limited extent. For instance, de Haas (2010) developed a general theoretical model explaining the rise, perpetuation, and decline of migrant networks and migration systems. He explicitly includes assimilation and transnational behaviour in his model as determinants. However, the model is described only in terms of general processes and determinants, and there is little theorizing about the direction of effects between model components. Furthermore, the model, to our knowledge, has not yet been empirically tested. Fokkema et al. (2012) investigated transnational behaviour of the second generation in several European and U.S. cities and found that only a minority exhibit transnational behaviour. Those that do are socio-culturally less well integrated and economically more integrated, and they reside more often in cities and in countries with an assimilation policy.

Snel, Engbersen, and Leerkes (2006) investigated the relationship between transnational and acculturation behaviour for different immigrant groups in the Netherlands and found that transnational behaviour does not affect acculturation behaviour. This finding was of interest to us when specifying our model, in particular regarding hypotheses about the direction of effects between acculturation style, transnational behaviour, and migration intention (Figure 1).

In terms of the effects of the two dimensions of acculturation (IGP and NSP), the expectation is that a rise in the preference for living according to Turkish norms, values, and customs (IGP) leads to stronger identification with Turkey, increased contact with people in Turkey, and increased migration intentions. Conversely, a rise in the preference for living according to majority-population norms, values, and customs (NSP) is expected to reduce identification with Turkey. However, because a transnational lifestyle is engrained in the lives of most of the second generation, we do not expect transnational behaviour to be much affected by change in NSP. Migration intentions, however, can be expected to be more sensitive to changes in NSP because an increase in identification with the norms of the majority population's values and customs will probably reduce intentions to migrate to Turkey. 
Several studies show that cultural distance impinges on acculturation style, transnational behaviour, and migration intentions. For instance, in their study on the acculturation style of the Turkish second generation in Europe, Groenewold, de Valk, and Van Ginneken (2014) found that higher levels of religiosity and exposure to discrimination are associated with higher preference for Turkish norms, values, and customs (IGP) and with lower preference for the norms of the majority population (NSP). Güngör and Bornstein (2009) found that indicators of cultural distance influence the acculturation of the Turkish second generation in Belgium. The study of Vedder, Sam, and Liebkind (2007) on the acculturation of the Turkish second generation in north-western Europe confirms this influence. Although the studies of Wessendorf (2013), Christou, and King (2015) and King and Kilinc (2013) use different indicators of cultural distance, they also conclude that cultural distance impinges on transnational behaviour and on roots-migration intentions of the second generation. Regarding our study population, we therefore expect that an increase in religiosity and perceived exposure to discrimination increases a person's orientation towards Turkey, increases transnational contact and activities with people in Turkey, and increases intention to migrate to Turkey. We expect that part of these effects is channelled through a person's acculturation style, whereby preference for NSP is expected to decrease, and preference for IGP to increase. In other words, we expect that acculturation style mediates part of the effect that cultural distance has on transnational behaviour and migration intention.

Personality traits are important in shaping preferences, attitudes, and behaviour. For example, a person's self-efficacy, which is the belief that they will be successful when performing a novel or challenging task, even under adverse conditions, shapes their approach to moving to another country. Highly self-efficacious people set goals, invest effort, persist in the face of barriers, and recover well from setbacks (Bandura 2001; Schwarzer and Jerusalem 1995). Studies suggest that migration intentions and actual migration are highest among highly self-efficacious people (e.g., de Jong and Fawcett 1981; Groenewold, de Bruijn, and Bilsborrow 2012), especially in settings where potential emigrants have to overcome considerable distances, barriers, and setbacks. We assume that self-efficacy has this effect for the Turkish second generation. We expect that people who are transnationally active and those considering migration to Turkey will generally be more self-efficacious. To our knowledge, the relationship between self-efficacy and acculturation style has not been examined yet. Common sense suggests that self-efficacy beliefs are not important to the explanation of variation in the degree of preference for living according to one's own ethnic group norms and values (IGP). However, it may be important in explaining preference for living according to majority population norms and values (NSP). Regarding our study population, we expect highly efficacious people to be self-confident and proud about their Turkish descent and cultural values. Compared to less efficacious people, such 
people will probably be less likely prefer to conform to the majority population's value system. Among such people, we can assume that critics of the majority population's value system will be found. Thus, we expect self-efficacy and NSP to be negatively associated.

Based on the above considerations, we derived a general theoretical model (Figure 1) for empirical investigation. Due to the cross-sectional nature of the empirical data, the general model is recursive, consisting of one-directional relationships between model variables. Such data does not permit incorporation of feedback effects, even though these effects may exist. For instance, migration intentions may become stronger or weaker after repeated visits to Turkey. Thus, our conclusions from testing the model strictly pertain to the simplified reality that the model expresses. We are aware, in the absence of proper longitudinal data, that we cannot prove causality between model variables by using cross-sectional data. However, we can test hypotheses about such relations. Therefore, the findings of our analyses of correlations can still be used as reference points to future studies based on longitudinal data. In the model, e1, e2, e3, and e4 represent error terms. They capture the influence of external factors on model variables over which we do not have control and about which we do not theorize, such as random shocks, misspecifications, measurement error, and other relevant variables that are not included in the data set (e.g., Kline 2011).

The double arrow between the error terms NSP and IGP indicates that these variables co-vary $(+/-)$, and that we account for this covariance computationally when estimating the other model parameters. Low and high positive covariances indicate a marginalization and integration style, respectively, while low and high negative covariances indicate a separation and assimilation style, respectively (e.g., Berry, Trimble, and Olmeda 1986). Indicators of self-efficacy and cultural distance are included as exogenous variables. Although the covariance of these variables is accounted for in the estimation of all path coefficients, it remains unanalysed because it is not part of our theorizing.

Figure 1 also shows that the positive effects of indicators of cultural distance and personality on transnational behaviour and migration intentions are expected to be partially mediated by the two indicators of acculturation style (i.e., NSP and IGP). Mediation through NSP is expected to attenuate (-) those effects, and through IGP to reinforce $(+)$ those effects. 
Figure 1: Structural model relating indicators of cultural distance and acculturation style to transnational behaviour and migration intentions

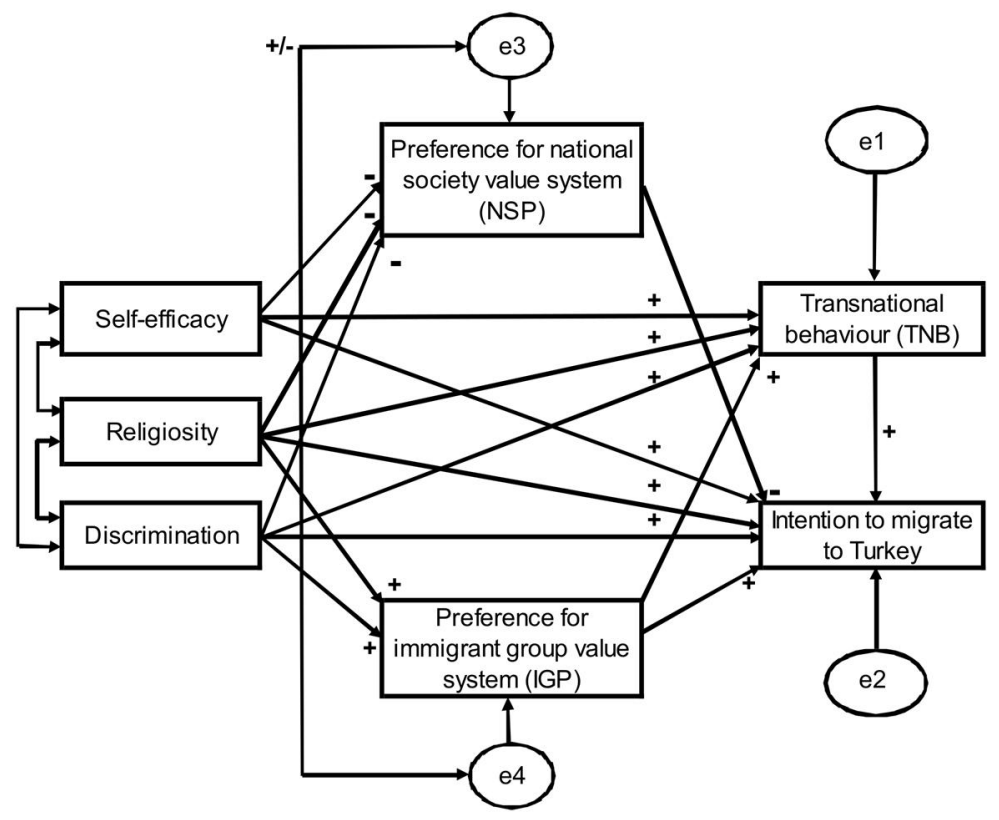

The model pertains to the whole of the second generation, irrespective of their place of residence. The validity of the model is tested by applying it to pooled and country-specific data. Goodness of fit to both types of datasets contributes to generalizability of the structure of the model, while country-specific configurations of the model are still feasible. However, only a few studies are available for deriving clues for hypotheses about such country-specific configurations, such as the studies of Snel, Engbersen, and Leerkes (2006); Groenewold, de Valk, and Van Ginneken (2014); and Huschek, de Valk, and Liefbroer (2012). For instance, access to welfare state entitlements and citizenship was found to differ between countries, ranging from very restrictive (Austria, Switzerland) to liberal (Sweden). Such differences were found to be linked to different acculturation styles and intentions to migrate to Turkey. Intentions to migrate away from a country with easy access to welfare state entitlements and citizenship (e.g., Sweden) were found to be lower than intentions to leave a country with more restricted access (e.g., Austria). Also, major societal events and migration policy shifts in one country (e.g., the Netherlands) may lead to certain pathways to 
become more or less pronounced for that country. Following Heath, Rothon, and Kilpi (2008), country-specific configurations may also result from differences in background characteristics of the parents, the degree of acceptance of the Turkish community by national majority populations, and the characteristics of migrant integration policies and the way they are implemented (more inclusionary or exclusionary).

\section{Data}

We use data from the Integration of the European Second Generation (TIES) project in which we participated. Between 2006 and 2008, young adults of three immigrant groups were surveyed in 15 major cities of eight European countries: Austria, Belgium, France, Germany, Netherlands, Spain, Sweden, and Switzerland (Hornstra, Groenewold, and Lessard-Phillips 2012). The project selected European countries with different migrant-integration philosophies and policies. For instance, Sweden and the Netherlands have migrant-integration policies reflecting the multicultural attitude of the national majority population, granting immigrant communities cultural rights, easy access to welfare state entitlements and citizenship, and offering them protection against cultural discrimination. However, since 2000, Dutch policies changed dramatically leading to imposing firmer demands regarding acquisition of good Dutch language skills, and (signed) consent to mainstream Dutch norms and values, and to religious tolerance (e.g., de Waal 2017). In the German-speaking countries, migrantintegration policies are far less inclusive. Immigrants and their children face higher barriers to citizenship and welfare state entitlements. The orientation of the French integration policy is assimilationist, but in a different way than in the German-speaking countries because the French policy endorses equality and equal access to welfare state entitlements at the individual level, but it discourages ethnic group and cultural diversity (Crul, Scheider, and Lelie 2012).

Within countries, we selected cities where most of members of particular immigrant groups concentrate. We sought respondents between 18 and 35 years old who were born and raised and reside in the survey country, with at least one parent born in Turkey, Morocco, or former Yugoslavia. A native comparison group in the same age range was also included (Crul, Schneider, and Lelie 2012). For our study, we used the data from Austria, Switzerland, Germany, the Netherlands, France, and Sweden countries where more than $90 \%$ of the Turkish second generation in Europe resides (Fargues 2005).

In each country, 500 respondents were sampled from each immigrant group, as well as 500 respondents from a native comparison group. Where possible, respondents were sampled in the same neighbourhoods. In Dutch and Swedish cities, they were 
sampled from municipal population registers whereby all person-records of (Turkish) second-generation citizens were sorted by neighbourhood. Subsequently, a fixed number of potential respondents was sampled from the sorted person-records (i.e., every $\mathrm{k}^{\text {th }}$ individual). In the German-speaking countries and France, access to population registers was not granted. Instead, a database of first and middle names, surnames, and other personal information was compiled from data that was obtained from different institutions, such as electricity boards and phone companies. Using special screening software, a sampling frame was derived, permitting the sampling of second-generation respondents. Native-born comparison group members were sampled using a random walk strategy whereby addresses of sampled second-generation respondents served as starting points.

Respondents were interviewed about issues such as educational attainment, labour market participation, partnership, cultural preferences, and identity, exposure to discrimination, religiosity, and psychosocial characteristics. Interviewer nonresponse was in the range of $40 \%$ to $60 \%$, which is comparable to other surveys of immigrant populations in Europe (Stoop 2005). Nonresponse bias was assessed by using the responses of interviewers on questions about how difficult it was to obtain information from each respondent. According to the continuum of resistance model (Lin and Schaeffer 1995) difficult-to-reach respondents can be used as proxies for unobserved nonrespondents. Easy and difficult-to-reach respondents appeared to differ only slightly.

Item nonresponse was low, except in the case of the Netherlands and France, where it was about $11 \%$ for the variables 'acculturation style' and 'experience with discrimination.' We examined characteristics of nonresponding people and found that they did not differ substantially in terms of age, sex, and marital status, although educational attainment was somewhat lower than that of responding people. We also examined whether inclusion or exclusion of nonrespondents for one variable affected the distributional characteristics of other variables on which nonrespondents did reply. This investigation did not reveal major biases (Groenewold and Lessard-Phillips 2012).

\section{Methods and variables}

The method of structural equation modelling (SEM) is applied, using covariance-based AMOS software (v.22). To estimate direct and indirect-effect coefficients, we apply the method of nonparametric bootstrapping (5,000 bootstrap samples) with bias-corrected confidence intervals (Arbuckle 2006; Kenny 2014; Kline 2011). Estimates of indirect effects and statistical power are derived from online software applications of Kenny (2017) and Soper (2017). Several model variables are scale variables derived from 
Likert items. If only a few items were available, a sum scale was derived. If more items were available, we used reliability analysis and confirmatory categorical principle components analysis (CATPCA). Scale scores were normalized to fit a $0-5$ or $0-10$ range (Linting et al. 2007; McIver and Carmines 1981).

Intention to migrate to Turkey was assessed from the response to the question about the likelihood that a respondent, in the future, intends to live in Turkey for one year or longer $(1=$ Certainly not, to $5=$ Most certainly).

Transnational behaviour (TNB) is represented by a sum scale $(0-10)$. The scale is based on proxy information about transnational behaviour (i.e., number of visits to Turkey, frequency of sending remittances to Turkey, and frequency of internet consultations about life in Turkey). We reasoned that if people frequently visit Turkey and remit money, they do so because they have important social capital in Turkey. Internet consultations about living conditions in Turkey express interest in contact and activities with people in Turkey.

The two-dimensional concept of acculturation style is measured by two distinct sum scales. The NSP scale (0-5) represents the degree of preference for the majority population's value system. The IPG scale (0-5) measures the degree of preference for the immigrant-group (Turkish) value system. IGP and NSP were derived from the following Likert items ( $1=$ Totally disagree, to $5=$ Totally agree) (Berry et al. 2006):

1. At home, people of immigrant origin have the right to live as much as possible in accordance with the cultural norms and customs of their parents' origin country or region.

2. At home, people of immigrant origin have the right to live as much as possible in accordance with the cultural norms and customs in (survey country).

3. Outside the home, people of immigrant origin have the right to live as much as possible in accordance with cultural norms and customs of their parents' origin country or region.

4. Outside the home, people of immigrant origin have the right to live as much as possible in accordance with cultural norms and customs of (survey country).

We assume that a respondent's opinion about the rights of others reflect expectations regarding the respondent's rights.

A short version of the general self-efficacy scale (0-10) (Schwarzer and Jerusalem 1995) was derived to indicate personality. The scale was derived by applying reliability analysis and CATPCA to the following Likert items $(1=$ Not true at all, to $4=$ Exactly true): 
1. I find it easy to stick to aims to accomplish my goals.

2. Problems can be resolved if I put effort in it.

3. In case of problems, I generally find a solution.

4. I am confident that I can successfully handle problems that come my way.

A religiosity scale (0-10) served as indicator of cultural distance. The scale was derived by applying reliability analysis and CATPCA to the response to the following Likert items ( $1=$ Totally agree, to $5=$ Totally disagree):

1. It is important to me to be (Muslim/Christian).

2. I am a religious person.

3. I feel strongly affiliated with peers of my religion.

4. I feel that I am similar to members of my own religious group.

5. I feel a personal relationship with God.

6. Religion is the ultimate political authority.

7. Showing religious symbols in public demonstrates religious commitment.

A perceived exposure to discrimination scale (0-10), another indicator of cultural distance, was derived after applying reliability analysis and CATPCA to Likert items on frequency of exposure to discrimination at school, in the neighbourhood, at restaurants, at other leisure-time destinations, at encounters with the police, and in dealings with government institutions $(1=$ Never, to $5=$ Frequently).

The validity of the theoretical model is assessed as follows. First, we examine whether the model fits well with both the pooled and country-specific data. Second, we examine whether the expected directions of effects in Figure 1 are confirmed by structural equation model estimates of path coefficients. This step is required because a model may fit well with empirical data, even if effects are predicted in the wrong direction. Good model fit and correctly predicted directions of effects lend support to the validity of the theoretical model. Third, we examine whether coefficients for direct and indirect pathways in Figure 1 are according to expectation. These coefficients are standardized regression coefficients, and they can be compared regarding the strength of the relationship between a given predictor variable and a dependent variable. As an aid for assessing and interpreting individual path coefficients, we carried out post hoc statistical power analysis. Statistical power depends on sample size, number of endogenous variables, and variance explained (R-square) by the predictors of each endogenous variable. If statistical power drops below .80, the conclusions that can be drawn from statistically significant path coefficients are jeopardized. 


\section{Results}

\subsection{Characteristics of the Turkish second generation}

Overall, age and sex profiles of respondents in the six countries are similar (data not shown but available from the first author). On average, respondents are between 24 (France) and 26 years (Germany) old, and in most samples female respondents are somewhat overrepresented, ranging from 51\% (Sweden) to 58\% (France).

Table 1 presents descriptive statistics of model variables. We found that about half of the respondents in all countries have, to some extent, an intention to migrate to Turkey. About 1 in 15 respondents is certain about such a move. Combining mean scores of NSP and IGP permit positioning into one of the four acculturation-style quadrants as described by Berry, Trimble, and Olmeda (1986). Mean scores based on pooled-country data suggest that the Turkish second generation, overall, prefers an integration style, whereby they aim to strike a balance between mainstream norms, values, and customs and those of the Turkish community. The second generation scores high on self-efficacy, intermediate on religiosity, and low on perceived exposure to discrimination.

Differences between countries are mostly small regarding descriptive statistics of model variables. However, in Austria, France, and the Netherlands, respondents express an intention to migrate to Turkey more often than respondents in Germany, Switzerland, and Sweden. Respondents in France and the Netherlands are more often transnationally active. Except in the Netherlands, the Turkish second generation in the study countries predominantly prefers an integration style (i.e., scores above 2.5 on IGP and NSP). The scores for the Dutch second generation indicate preference for a separation style. A possible explanation for this may be that interviews were conducted in a period of inter-ethnic tension in the aftermath of the assassination of two critics of Islam - politician Pim Fortuyn and filmmaker Theo van Gogh - and the death threats to politician Ayaan Hirsi Ali for criticizing Islamic support for the subjugation of women. Positioning in the separation quadrant may indicate distrust between Islamic communities and the Dutch majority population.

Moving on to the constructs of self-efficacy, religiosity, and discrimination, the high Cronbach $\alpha$ scores indicate that the derived scales are reliable. Self-efficacy among the Turkish second generation in Germany, Switzerland, and the Netherlands is high, and is somewhat lower in France and Sweden. Religiosity among the second-generation Turkish immigrants to Switzerland, Germany, and Sweden is low, and is high in France and Austria. Perceived exposure to discrimination is low in all countries, ranging from 0.5 in Sweden to 3.3 in Austria (on a 10-point scale). 
Table 1: Descriptive statistics of model variables, pooled and country data

\begin{tabular}{|c|c|c|c|c|c|c|c|c|}
\hline & & $\begin{array}{l}\text { Pooled } \\
\text { countries }\end{array}$ & Austria & Germany & Switzerland & France & Netherlands & Sweden \\
\hline \multirow[t]{5}{*}{ Emigration intention } & Certainly not & 48 & 31 & 59 & 59 & 35 & 45 & 59 \\
\hline & Possibly & 36 & 54 & 35 & 32 & 31 & 34 & 26 \\
\hline & Likely & 10 & 12 & 5 & 5 & 17 & 9 & 11 \\
\hline & Certainly & 7 & 4 & 1 & 4 & 17 & 13 & 5 \\
\hline & Total & 100 & 100 & 100 & 100 & 100 & 100 & 100 \\
\hline Transnational behaviour (TNB) & Mean & 3.4 & 2.8 & 2.2 & 3.2 & 4.8 & 4.4 & 3.2 \\
\hline (scale range $0-10$ ) & Std. dev. & 2.6 & 2.3 & 2.2 & 2.1 & 2.5 & 2.7 & 2.6 \\
\hline Preference for national society & Mean & 3.6 & 3.6 & 3.9 & 3.6 & 3.8 & 2.4 & 4.5 \\
\hline value system (NSP) & Std. dev. & 1.2 & 1.2 & 0.8 & 1.0 & 1.1 & 1.1 & 0.8 \\
\hline \multicolumn{9}{|l|}{ (scale range $0-5$ ) } \\
\hline Preference for Turkish society & Mean & 3.5 & 3.4 & 3.8 & 3.3 & 3.7 & 3.5 & 3.4 \\
\hline value system (IGP) & Std. dev. & 1.1 & 1.2 & 0.9 & 1.0 & 0.9 & 1.0 & 1.4 \\
\hline \multicolumn{9}{|l|}{ (scale range $0-5$ ) } \\
\hline Self-efficacy & Mean & 7.9 & 7.9 & 8.9 & 8.9 & 6.8 & 8.2 & 5.7 \\
\hline \multirow[t]{2}{*}{ (scale range $0-10$ ) } & Std. dev. & 2.1 & 1.7 & 1.1 & 0.9 & 2.4 & 2.0 & 2.2 \\
\hline & Cronbach $\alpha$ & & 0.86 & 0.84 & 0.75 & 0.80 & 0.82 & 0.81 \\
\hline Religiosity & Mean & 6.3 & 7.2 & 5.9 & 4.4 & 7.6 & 6.7 & 5.9 \\
\hline \multirow[t]{2}{*}{ (scale range $0-10$ ) } & Std. dev. & 3.8 & 3.8 & 4.0 & 4.0 & 3.1 & 2.7 & 3.8 \\
\hline & Cronbach $\alpha$ & & 0.93 & 0.94 & 0.91 & 0.92 & 0.92 & 0.90 \\
\hline Discrimination & Mean & 2.2 & 3.5 & 3.1 & 1.4 & 2.7 & 1.3 & 0.5 \\
\hline \multirow[t]{3}{*}{ (scale range $0-10$ ) } & Std. dev. & 2.4 & 3.1 & 2.2 & 1.6 & 2.6 & 1.6 & 1.3 \\
\hline & Cronbach $\alpha$ & & 0.90 & 0.92 & 0.80 & 0.80 & 0.75 & 0.71 \\
\hline & $\mathrm{n}$ & 2,418 & 431 & 503 & 454 & 434 & 355 & 241 \\
\hline
\end{tabular}

\subsection{Linkages between acculturation style, transnational behaviour, migration intentions, and their determinants}

As a first step in the analysis, Table 2 presents model-fit scores on eight widely established goodness-of-fit indices (e.g., Hooper, Coughlan, and Mullen 2008; Kenny 2014; Kline 2011).

The first six indices are absolute fit indices. They assess how well the covariance matrix is predicted by our restricted model (15 direct pathways) in comparison with a saturated version (17 direct pathways). The indices in the last two columns in the table are incremental fit indices, which assess how much better our model predicts observed correlations between model variables compared to the null hypothesis that model variables are uncorrelated. These indices differ regarding their sensitivity to sample size and model complexity. Compared to their cut-off values, index values in Table 2 indicate that the theoretical model (Figure 1) fits well with the empirical data from both pooled and individual countries. In Germany and Switzerland only, TLI values are 
somewhat below the .95 cut-off value. However, values of other indices are good to excellent for these countries.

Table 2: Goodness-of-fit of theoretical model (Figure 1) to country data

\begin{tabular}{|c|c|c|c|c|c|c|c|c|c|}
\hline & $\mathbf{n}$ & $\begin{array}{l}\text { Chi-square } \\
X^{2}(P>0.05)\end{array}$ & $\begin{array}{l}\text { Chi-square/df } \\
(<5.00)\end{array}$ & $\begin{array}{l}\text { RMSEA } \\
(0.00-0.08)\end{array}$ & $\begin{array}{l}\text { PCLOSE } \\
(P>0.05)\end{array}$ & $\begin{array}{l}\text { AGFI } \\
(>0.95)\end{array}$ & $\begin{array}{l}\text { SRMR } \\
(<0.08)\end{array}$ & $\begin{array}{l}\text { TLI } \\
(>0.95)\end{array}$ & $\begin{array}{l}\text { CFI } \\
(>0.95)\end{array}$ \\
\hline Pooled countries & 2,418 & $1.82(P=.40)$ & 0.91 & 0.00 & 0.99 & 0.99 & 0.01 & 1.00 & 1.00 \\
\hline Austria & 431 & $0.71(P=.70)$ & 0.36 & 0.00 & 0.88 & 0.99 & 0.01 & 1.00 & 1.00 \\
\hline Germany & 503 & $6.09(P=.05)$ & 3.05 & 0.06 & 0.27 & 0.95 & 0.02 & 0.92 & 0.99 \\
\hline Switzerland & 454 & $4.94(\mathrm{P}=.09)$ & 2.47 & 0.06 & 0.33 & 0.96 & 0.02 & 0.86 & 0.99 \\
\hline France & 504 & $0.98(P=.61)$ & 0.49 & 0.00 & 0.83 & 0.99 & 0.01 & 1.00 & 1.00 \\
\hline Netherlands & 355 & $0.17(P=.92)$ & 0.09 & 0.00 & 0.97 & 0.99 & 0.00 & 1.00 & 1.00 \\
\hline Sweden & 241 & $0.75(P=.37)$ & 0.37 & 0.00 & 0.81 & 0.98 & 0.01 & 1.00 & 1.00 \\
\hline
\end{tabular}

The second step in the analysis is to examine whether theory-predicted directions of effects are confirmed empirically. Table 3 includes a column with the expected effect-directions presented in Figure 1. The upper part of the table comprises, for pooled and individual countries, coefficients associated with the direct-effect pathways in Figure 1. The bottom part of the table presents estimates of coefficients of indirect/mediation effects. Furthermore, R-square values are reported to express the percentage of variance explained by model variables. They are also used to determine the statistical power of pathways between endogenous model variables (e.g., Soper 2017). Findings in Table 3 show that most of the expected directions of coefficients are indeed empirically confirmed, lending further support for overall validity of the theoretical model, except in three instances.

First, the pooled-countries coefficient for the discrimination $\rightarrow$ NSP effect is the opposite of the expected direction. This may be due to the relatively large role that this effect plays in Austria. The unexpected direction is not attributable to poor statistical power, which is larger than 0.80 (i.e., 1.0 for all paths leading to NSP). An explanation might be that the strong pressure of the Austrian majority population on immigrant communities to adjust and conform to Austrian norms, values, and customs is interpreted by the Turkish second generation as a message of exclusion and discrimination, in particular by about $12 \%$ of the respondents, who were born in and are residing in Austria who do not hold but want Austrian citizenship (also see Crul, Schneider, and Lelie 2012).

The strong demands of the Austrian majority population combined with fear among part of the second generation of not obtaining Austrian citizenship may lead to socially desirable response on questions about acculturation style. 
Groenewold \& de Valk: Acculturation style, transnational behaviour, and return-migration intentions

Table 3: $\quad$ Standardized regression (path) coefficients of hypothesized relationships between model variables (Figure 1)

\begin{tabular}{|c|c|c|c|c|c|c|c|c|c|c|}
\hline & & \multicolumn{2}{|c|}{$\begin{array}{r}\text { Expected } \\
\text { effect }\end{array}$} & $\begin{array}{l}\text { Pooled } \\
\text { countries }\end{array}$ & Austria & Germany & Switzerland & France & Netherlands & Sweden \\
\hline \multicolumn{11}{|l|}{ Direct effects } \\
\hline TNB & $\rightarrow$ & $\begin{array}{l}\text { Migration } \\
\text { intention }\end{array}$ & + & 0.24 ** & 0.30 ** & 0.21 ** & 0.14 ** & $0.18^{* *}$ & 0.28 ** & $0.33^{* *}$ \\
\hline NSP & $\rightarrow$ & $\begin{array}{l}\text { Migration } \\
\text { intention }\end{array}$ & - & -0.01 & -0.04 & -0.01 & -0.02 & -0.01 & -0.06 & 0.04 \\
\hline IGP & $\rightarrow$ & $\begin{array}{l}\text { Migration } \\
\text { intention }\end{array}$ & + & $0.06^{\star \star}$ & 0.11 * & $0.10 \dagger$ & 0.00 & 0.14 ** & 0.04 & 0.01 \\
\hline IGP & $\rightarrow$ & TNB & + & $0.11^{* *}$ & 0.22 ** & $0.08 \dagger$ & 0.03 & $0.07 t$ & $0.18^{* *}$ & 0.07 \\
\hline Self-efficacy & $\rightarrow$ & NSP & - & 0.03 & -0.01 & 0.05 & 0.05 & 0.08 & 0.02 & 0.04 \\
\hline Religiosity & $\rightarrow$ & NSP & - & -0.01 & $-0.11^{\star *}$ & 0.04 & -0.01 & -0.04 & 0.06 & 0.06 \\
\hline Religiosity & $\rightarrow$ & IGP & + & $0.16^{\text {** }}$ & 0.04 & $0.28^{* *}$ & $0.09 t$ & $0.12^{* *}$ & 0.29 ** & $0.22^{* \star}$ \\
\hline Discrimination & $\rightarrow$ & NSP & - & 0.05 * & $0.38^{* *}$ & -0.01 & -0.03 & 0.04 & -0.22 ** & $0.09 \dagger$ \\
\hline Discrimination & $\rightarrow$ & IGP & + & $0.13^{* *}$ & $0.44^{* *}$ & 0.06 & $0.09 \dagger$ & 0.00 & $0.15^{\star *}$ & -0.02 \\
\hline Self-efficacy & $\rightarrow$ & TNB & + & $0.08^{* *}$ & $0.09 t$ & 0.14 ** & 0.05 & 0.20 ** & 0.08 & $-0.11 \dagger$ \\
\hline Self-efficacy & $\rightarrow$ & $\begin{array}{l}\text { Migration } \\
\text { intention }\end{array}$ & + & $-0.06^{* *}$ & $-0.07 \dagger$ & -0.04 & -0.02 & -0.03 & -0.13 * & 0.01 \\
\hline Religiosity & $\rightarrow$ & TNB & + & 0.14 ** & 0.17 ** & 0.22 ** & 0.24 ** & $0.10^{* *}$ & 0.07 & -0.07 \\
\hline Religiosity & $\rightarrow$ & $\begin{array}{l}\text { Migration } \\
\text { intention }\end{array}$ & + & $0.14^{* *}$ & $0.25^{* *}$ & $0.27^{* *}$ & 0.11 * & $0.09^{*}$ & 0.03 & 0.07 \\
\hline Discrimination & $\rightarrow$ & TNB & + & $0.08^{* *}$ & $0.18^{* *}$ & $0.12^{* *}$ & 0.06 & 0.01 & -0.01 & 0.01 \\
\hline Discrimination & $\rightarrow$ & $\begin{array}{l}\text { Migration } \\
\text { intention }\end{array}$ & + & $0.12^{\text {** }}$ & $0.18^{* *}$ & $0.08 \dagger$ & 0.11 ** & 0.14 ** & 0.11 * & $0.33^{* *}$ \\
\hline Indirect/media & ation effec & & & & & & & & & \\
\hline Self-efficacy & $\rightarrow \mathrm{NSP} \rightarrow$ & $\begin{array}{l}\text { Migration } \\
\text { intention }\end{array}$ & - & 0.00 & 0.00 & 0.00 & 0.00 & 0.00 & 0.00 & 0.00 \\
\hline Religiosity & $\rightarrow \mathrm{NSP} \rightarrow$ & $\begin{array}{l}\text { Migration } \\
\text { intention }\end{array}$ & - & 0.00 & 0.00 & 0.00 & 0.00 & 0.00 & 0.00 & 0.00 \\
\hline Discrimination - & $\rightarrow \mathrm{NSP} \rightarrow$ & $\begin{array}{l}\text { Migration } \\
\text { intention }\end{array}$ & - & 0.00 & 0.00 & 0.00 & 0.00 & 0.00 & 0.00 & 0.00 \\
\hline Religiosity & $\rightarrow \mathrm{IGP} \rightarrow$ & TNB & + & $0.02^{* *}$ & 0.00 & 0.02 * & 0.00 & $0.01 \dagger$ & $0.05^{\text {** }}$ & 0.00 \\
\hline Discrimination - & $\rightarrow \mathrm{IGP} \rightarrow$ & TNB & + & 0.01 ** & 0.09 ** & 0.00 & 0.00 & 0.00 & 0.00 & 0.00 \\
\hline Religiosity & $\rightarrow \mid \mathrm{GP} \rightarrow$ & $\begin{array}{l}\text { Migration } \\
\text { intention }\end{array}$ & + & 0.01 ** & 0.00 & $0.03 \dagger$ & 0.00 & 0.02 ** & 0.00 & 0.00 \\
\hline Discrimination - & $\rightarrow \mathrm{IGP} \rightarrow$ & $\begin{array}{l}\text { Migration } \\
\text { intention }\end{array}$ & + & 0.01 ** & $0.05 \dagger$ & 0.00 & 0.00 & 0.00 & 0.00 & 0.00 \\
\hline IGP & $\rightarrow \mathrm{TNB} \rightarrow$ & $\begin{array}{l}\text { Migration } \\
\text { intention }\end{array}$ & + & $0.01^{\star *}$ & $0.07^{* *}$ & $0.01 \dagger$ & 0.00 & $0.01 \dagger$ & 0.00 & 0.00 \\
\hline Covariance & & & & & & & & & & \\
\hline IGP & $\leftrightarrow$ & NSP & $+/-$ & $0.41^{* *}$ & 0.60 ** & 0.62 ** & $0.53^{* *}$ & 0.28 ** & $-0.11 \dagger$ & $0.18^{* *}$ \\
\hline R-square and & statistica & al power & & & & & & & & \\
\hline IGP & & & & $5 \% \quad 1.0$ & $20 \% \quad 1.0$ & $9 \% \quad .99$ & $2 \% \quad .78$ & $1 \% .45$ & $11 \% \quad .99$ & $5 \% \quad .90$ \\
\hline NSP & & & & $1 \% \quad .97$ & $15 \% \quad 1.0$ & $1 \% \quad .45$ & $1 \% \quad .41$ & $1 \% .39$ & $5 \%$ & $1 \% \quad .22$ \\
\hline TNB & & & & $5 \% \quad 1.0$ & $14 \% \quad .99$ & $9 \% \quad .99$ & $7 \% \quad .99$ & $6 \% \quad .99$ & $5 \%$ & $2 \% \quad .39$ \\
\hline Migration intent & tion & & & $13 \% \quad 1.0$ & $30 \% \quad 1.0$ & $20 \% \quad 1.0$ & $5 \% \quad .97$ & $9 \% \quad .99$ & $11 \% \quad .99$ & $12 \% \quad .99$ \\
\hline $\bar{n}$ & & & & 2,418 & 431 & 503 & 454 & 434 & 355 & 241 \\
\hline
\end{tabular}

Note: $\dagger,{ }^{*},{ }^{* *}$ statistical significance at $10 \%, 5 \%, 1 \% ;+=$ positive effect, $-=$ negative effect, $+/-=$ positive or negative effect.

Second, contrary to expectation, we found that high self-efficacy seems to be associated with low instead of high migration intentions. An explanation might be that building a satisfactory and successful life in their EU country of birth is perceived as 
much more challenging, requiring higher self-efficacy than migration to Turkey does. If so, a transnational lifestyle is preferred over migration to Turkey. The latter is supported by the finding that the Self-efficacy $\rightarrow$ TNB association is positive.

Third, in Sweden, the signs for the path coefficients Discrimination $\rightarrow$ NSP and Self-efficacy $\rightarrow$ TNB are the opposite of our expectation. This may be due to the low $(<.80)$ statistical power of estimates of coefficients for pathways leading to NSP and to TNB, which is .22 and .39 , respectively, jeopardizing conclusions drawn from these coefficients.

As the third step in our analyses, we evaluated the direct and indirect path coefficients presented in Table 3. Coefficients for pooled-country data indicate that almost all of the direct-effect coefficients are statistically significant, and that the largest effect is the positive effect of transnational behaviour on migration intentions. Effects of religiosity and discrimination on preference for the Turkish value system (IGP) and on intention to migrate to Turkey are also relatively large.

Regarding indirect-effect coefficients, results confirm the hypothesis that acculturation style mediates part of the effects that indicators of cultural distance have on transnational behaviour and on migration intentions. However, mediation is only through one of the two dimensions of acculturation style. Thus, part of the effects of perceived exposure to discrimination and religiosity on transnational behaviour and migration intention are channelled only through the degree of preference for the Turkish value system (IGP). In general, compared to the size of direct-effect coefficients, the size of indirect-effect coefficients is small because they result from multiplying two direct-effect coefficients. The positive covariance coefficients between IGP and NSP in Table 3 indicate that, across the board, the Turkish second generation maintains an integration style. This is consistent with findings derived from the descriptive statistics of IGP and NSP in Table 1. Statistical significance of model coefficients based on pooled-country data is supported by high statistical power $(>.80)$. The results support the conclusions that, across the board and except for the three direct-effect coefficients mentioned previously, the theoretical model correctly describes how acculturation style, transnational behaviour, and migration intentions of the Turkish second generation are related and determined by cultural distance and self-efficacy. Country-specific results indicate that some pathways are more important in one country than in another one. Such country-specific configurations of the general model can be interpreted as 'characterizing' the situation in those countries.

Results for Austria resemble those of the general model. However, some pathways stand out, such as the effect that cultural distance - in particular, perceived discrimination - has on the degree of preference for living according to Austrian or Turkish norms and values. Other important pathways are the effects that indicators of cultural distance have on transnational behaviour and on intention to migrate to Turkey. 
Thus, strong feelings of being discriminated against and strong Islam religiosity increase transnational behaviour and migration intentions, and they also lead to higher preference for a lifestyle combining Turkish and Austrian norms, values, and customs. As we argued before, there may be some unknown bias involved, given that openly rejecting Austrian norms and values is not a wise thing to do in a country where access to permanent citizenship is difficult.

Contrary to the situation in Austria, the religiosity dimension of cultural distance characterizes the German and Swiss configurations of the general model. In Germany, strong religiosity is associated with strong preference for Turkish values, and it increases transnational behaviour and the intention to migrate to Turkey. In Switzerland, however, preference for living according Turkish values does not seem to influence transnational behaviour and migration intentions. The French configuration is characterized by the positive effects that indicators of cultural distance and self-efficacy have on transnational behaviour and on migration intentions. These effects are mediated, in part, by preference for living according to Turkish values (IGP). The Dutch configuration is predominantly shaped by effects that indicators of cultural distance and self-efficacy have on the preference for living according to Turkish values (IGP), and by the effect that IGP has on transnational behaviour. The Swedish configuration is determined by a few pathways only: notably, the effect of perceived discrimination on migration intention and the effect of religiosity on preference for living according to Turkish community values and customs. A problem with interpreting the results for Sweden is that coefficients and statistical significance for pathways to NSP and TNB are not reliable because statistical power is very low $(<.80)$ (see Kenny 2017; Soper 2017).

Despite showing differences in country configurations, Table 3 shows that countries also share common features. First, in all countries, transnational behaviour of the Turkish second generation is positively associated with intentions to migrate to Turkey, indicating that such behaviour may be interpreted as a stage in the migration decision-making process. Second, in all countries, feelings of being discriminated against increase intentions to migrate to Turkey. Third, a rise in religiosity is associated with an increase in the preference for living according to Turkish values. Such an increase also seems to lead to more transnational activities and contact with people in Turkey, which, as mentioned before, may increase intentions to migrate to Turkey in future. Fourth, based on the covariance coefficients, the Turkish second generation prefers an integration style in all countries except the Netherlands, where the second generation prefers a separation style. 


\section{Discussion}

This article explores linkages between acculturation, transnational behaviour, and international migration and the roles of cultural distance and personality. Our study population is young adults of Turkish parentage who were born and raised and reside in European countries. We developed a general theoretical model and tested it by using survey data collected in six countries with different migrant-integration philosophies and policies (Crul, Schneider, and Lelie 2012). The data for the Netherlands may be somewhat biased because it was collected in the aftermath of the assassination of two critics of Islam and after the implementation of major shifts in migration and integration policies. This may have raised feelings of discrimination among the Turkish second generation, resulting in respondents expressing more often a preference for Turkish community norms and values, and a preference for a separation acculturation style.

We tested the general validity of our theoretical model by examining whether the model fitted well with the survey data from the six study countries and to pooledcountry data. Results lend support for all hypotheses and for the validity of the theoretical model. They also indicate that country-specific configurations apply because certain model pathways are more pronounced in one country than in other countries. Results indicate that the Turkish second generation raised and residing in different countries are quite different regarding the characteristics examined in this study.

We also tested whether acculturation style mediates some of the effects that indicators of cultural distance and personality have on transnational behaviour and migration intentions. We found that such effects are mainly mediated through one of the two dimensions of acculturation style: the degree of preference for relying on immigrant group norms, values, and customs. This finding bears relevance to policy and public debate because measures counteracting negative stereotyping of Islam apparently pay off, not so much in terms of higher identification with majority population norms and values, but in terms of lowering identification with Turkish community norms and values.

The presence of country-configurations of the general model does not preclude that several important pathways are shared. First, transnational behaviour seems to foster intentions to migrate to Turkey in all countries. This is contrary to expectation according to the literature where a transnational lifestyle is presented as an alternative to emigration (e.g., Levitt 2009; Levitt and Jaworsky 2007). The latter probably applies to most first-generation immigrants but not to the (Turkish) second generation, as our results suggest that transnational behaviour and return-migration intentions are positively related. Barring the intention-behaviour gap (e.g., Ajzen 1991, 2014) it may be true that transnational behaviour paves the ground for counter-diasporic migration (e.g., Christou and King 2015). Increased involvement in transnational contact and 
activities may increase intentions to migrate and eventually lead to actual return migration, especially if living conditions in Turkey become more attractive and conditions in EU countries worsen due to the increase of discrimination and social exclusion. Second, in all countries, perceived discrimination is correlated with higher migration intentions. This finding is of particular concern to policymakers as it may lead well-educated and skilled members of the second generation to migrate to Turkey. This is undesirable in light of declining working-age populations in Europe, especially in Germany, where most of the Turkish second generation live and where the size of the working-age population has already been declining (e.g., Groenewold, de Beer, and de Valk 2016). Third, in all countries except the Netherlands, the covariance between IGP and NSP, defining acculturation style, is positive. This implies that the Turkish second generation generally favours an integration acculturation style.

Contrary to expectation, our indicator of personality, namely self-efficacy, was not found to be an important determinant of acculturation style, transnational behaviour, and migration intention. There may be several reasons for this. One reason may be that self-efficacy is simply less relevant to the explanation of such behaviour for secondgeneration Turkish migrants than for first-generation migrants who intend to move over a great distance to a country with a different culture. The Turkish second generation is born and raised within a context of well-established transnational networks of parents, while travel to Turkey is short, convenient, and inexpensive. Moving to Turkey may not be perceived as a challenging undertaking. Another reason might be that the explanation of acculturation, transnational, and migration behaviour requires a domainspecific self-efficacy scale instead a single, general self-efficacy scale (e.g., Schwarzer and Jerusalem 1995). Although our model may equally apply to first-generation potential-return migrants in receiving countries, incorporation of the self-efficacy construct is only warranted if acculturation and return migration involve certain challenges and sacrifices (e.g., Luszczynska, Gutierrez-Dona, and Schwarzer 2005).

The Swedish configuration of the model deviates considerably from those of other countries. One reason for this is that statistical significance of path coefficients is sensitive to the relatively smaller size of the Swedish sample. Related to this is that the statistical power associated with certain pathways turned out to be low, in particular for NSP and TNB, making it difficult to draw conclusions from coefficients for particular pathways (e.g., Kenny 2017; Soper 2017). Another reason might be that the SwedishTurkish community, contrary to the other study countries, is mainly composed of firstgeneration immigrants (and children born in Sweden) who are refugees identifying with Assyrians, a Christian minority prosecuted in eastern Turkey, or with Turkish Kurds. With this background, migration of the second generation to Turkey is less obvious, although transnational behaviour is of course still conceivable. Furthermore, such background characteristics may lead these immigrants to identify more strongly with 
the culture of the Swedish majority population. Research of Westin (2003) indeed confirms that the Swedish-Turkish second generation identifies strongly with many aspects of the Swedish way of life and culture. This strong identification is also supported by our data, as more than $30 \%$ of the Turkish second generation state that they prefer an assimilation style. In other countries, this identification ranges between 5\% (the Netherlands) and 18\% (Switzerland). (Data is not shown, but see Groenewold, de Valk, and Van Ginneken 2014.)

Another issue that was revealed by taking a closer look to the data is that characteristics of the parents of the Turkish second generation differ between countries. For instance, while parents of the Swedish-Turkish second generation are mainly refugees from rural Turkey, parents of the German-Turkish second generation are mainly labour migrants recruited from Istanbul. To come to grips with the precise reasons for country differences and country configurations of our model, future research on the second generation could include qualitative research about how differences in parental characteristics shape acculturation preferences, transnational behaviour, and migration intentions of children, and about the role of institutional, political, and contextual factors. Proper person-level indicators could then be derived from qualitative research and included in surveys.

Overall, our study shows that it is important to study linkages between acculturation, transnational behaviour, and return-migration intentions. The ways in which migration intentions translate into actual migration would be an interesting avenue for future research. Furthermore, it is important to investigate these linkages in other immigrant groups also. This research will contribute to a better general understanding of the mechanisms at work in the decision-making of young adults of immigrant origin regarding why and how they navigate between parental origin countries and their European country of residence.

\section{Acknowledgements}

The authors gratefully acknowledge the helpful suggestions of the three anonymous reviewers and the guest editor, Dr. Helen Baykara-Krumme. The work of the second author was supported by the European Research Council Starting Grant project, 'Families of migrant origin: a life course perspective' (project number 263829), awarded to Helga A.G. de Valk. Previous versions of this paper were presented at the IMISCOE 10th Annual Conference, 25-28 August 2013, Malmö, Sweden, and the European Population Conference, 25-28 June 2014, Budapest, Hungary. 


\section{References}

Ajzen, I. (1991). The theory of planned behavior. Organizational Behavior and Human Decision Processes 50: 179-211. doi:10.1016/0749-5978(91)90020-T.

Ajzen, I. (2014). The theory of planned behaviour is alive and well, and not ready to retire: A commentary on Sniehotta, Presseay and Araújo-Soares. Health Psychology Review 9(2): 131-137. doi:10.1080/17437199.2014.883474.

Alba, R. and Nee, V. (2003). Bright versus blurred boundaries: Second-generation assimilation and exclusion in France, Germany, and the United States. Ethnic and Racial Studies 28(1): 20-49. doi:10.1080/0141987042000280003.

Aleksynska, M. and Chiswick, B.R. (2011). Religiosity and migration: Travel into one's self versus travel across cultures. Bonn: IZA Institute for the Study of Labor (IZA Discussion Paper Series No. 5724).

Arbuckle, J.L. (2006). Amos (version 7.0) [computer software]. Chicago: SPSS.

Bandura, A. (2001). Social cognitive theory: An agentic perspective. Annual Review of Psychology 52: 1-26. doi:10.1146/annurev.psych.52.1.1.

Bean, F.D., Brown, S.K., Bachmeier, J.D., Fokkema, T., Lessard-Phillips., L., and Mollenkopf, J. (2010). Urban contexts and immigrant integration: A comparative examination of second-generation incorporation in US and European cities. New York: Russell Sage.

Becker, B. (2010). The transfer of cultural knowledge in the early childhood: Social and ethnic disparities and the mediating role of familial activities. European Sociological Review 26(1): 17-29. doi:10.1093/esr/jen081.

Berry, J.W. (1990). Psychology of acculturation. In: Berman, J.J. (ed.). Nebraska Symposium on motivation, cross-cultural perspectives, current theory and research in motivation. Lincoln: University of Nebraska Press: 201-234.

Berry, J.W. (1997). Immigration, acculturation, and adaptation. Applied Psychology: An International Review 46(1): 5-34. doi:10.1111/j.1464-0597.1997.tb01087.x.

Berry, J.W., Kim, U., Minde, T., and Mok, D. (1987). Comparative studies of acculturative stress. International Migration Review 21(3): 491-511. doi: $10.2307 / 2546607$.

Berry, J.W., Phinney, J.S., Sam, D.L., and Vedder, P. (2006). Immigrant youth: Acculturation, identity and adaptation. Applied Psychology: An International Review 55(3): 303-332. doi:10.1111/j.1464-0597.2006.00256.x. 
Berry, J.W. and Sabatier, C. (2010). Acculturation, discrimination, and adaptation among second generation immigrant youth in Montreal and Paris. International Journal of Intercultural Relations 34(3): 191-207. doi:10.1016/j.ijintrel.2009. 11.007.

Berry, J.W., Trimble, J.E., and Olmeda, È.L. (1986). The assessment of acculturation. In: Lonner, W.J. and Berry, J.W. (eds.). Field methods in cross-cultural research. Beverly Hills: Sage: 291-324.

Bourhis, R.Y., Moise, L.C., Perreault, S., and Senecal, S. (1997). Towards an interactive acculturation model: A social psychological approach. International Journal of Psychology 32(6): 369-386.

Castles, S., de Haas, H., and Miller, M.J. (2014). The age of migration: International population movements in the modern world. London: Palgrave Macmillan. doi:10.1007/978-0-230-36639-8.

Christou, A. and King, R. (2015). Counter-diaspora: The Greek second generation returns 'home.' Cambridge: Harvard University Press.

Crul, M. and Schneider, J. (2010). Comparative integration context theory: Participation and belonging in new diverse European cities. Ethnic and Racial Studies 33(7): 1249-1268. doi:10.1080/01419871003624068.

Crul, M., Schneider, J., and Lelie, F.E. (2012). The European second generation compared: Does the integration context matter? Amsterdam: Amsterdam University Press.

de Haas, H. (2010). The internal dynamics of migration processes: A theoretical inquiry. Journal of Ethnic and Migration Studies 36(10): 1587-1617. doi:10.1080/1369183X.2010.489361.

de Jong, G.F. (1994). Choice processes in migration intentions and behavior. University Park: Pennsylvania State University (Working Paper 95-04).

de Jong, G.F. (2000). Expectations, gender, and norms in migration decision-making. Population Studies 54(3): 307-319. doi:10.1080/713779089.

de Jong, G.F. and Fawcett, J.T. (1981). Motivation for migration: An assessment and a value expectancy research model. In: de Jong, G.F. and Gardner, R.W. (eds.). Migration decision making: Multidisciplinary approaches to microlevel studies in developed and developing countries. New York: Pergamon Press: 13-53. doi:10.1016/B978-0-08-026305-2.50008-5. 
de Waal, T.M. (2017). Conditional belonging: A legal-philosophical inquiry into integration requirements for immigrants in Europe [PhD thesis]. Amsterdam: University of Amsterdam, Faculty of Law. http://hdl.handle.net/11245.1/ aa9a125e-5ebe-425a-90de-4a9578e3cefb.

Dona, G. and Berry, J.W. (1994). Acculturation attitudes and acculturative stress of Central American refugees. International Journal of Psychology 29(1): 57-70. doi:10.1080/00207599408246532.

Fargues, P. (2005). How many migrants from, and to, Mediterranean countries of the Middle East and North Africa? Florence: European University Institute (CARIM Analytic and Synthetic Notes 2005/16). http://cadmus.eui.eu/handle/1814/11684.

Fokkema, T., Lessard-Phillips, L., Bachmeier, J., and Brown, S. (2012). The link between the transnational behaviour and integration of the second generation in European and American Cities. Nordic Journal of Migration Research 2: 111. doi:10.2478/v10202-011-0033-x.

Gallup International (2012). Global index of religiosity and atheism: 2012 [electronic resource]. Washington, D.C.: Gallup International. http://www.wingia.com/web/ files/news/14/file/14.pdf.

Groenewold, G., de Bruijn, B., and Bilsborrow, R. (2012). Psychosocial factors of migration: Adaptation and application of the health belief model. International Migration 50(6): 211-231. doi:10.1111/j.1468-2435.2012.00781.x.

Groenewold, G., de Valk, H.A.G., and Van Ginneken, J. (2014). Acculturation preferences of the Turkish second generation in 11 European cities. Urban Studies 51(10): 2125-2142. doi:10.1177/0042098013505890.

Groenewold, G. and Lessard-Phillips, L. (2012). Research methodology. In: Crul, M., Schneider, J., and Lelie, F. (eds.). The European second generation compared: Does the integration context matter? Amsterdam: Amsterdam University Press: 39-56.

Groenewold, W.G.F., de Beer, J.A.A., and de Valk, H.A.G. (2016). Prospects of labour migration pressure in Algeria, Morocco, Tunisia and Turkey. Genus 72(8). doi:10.1186/s41118-016-0015-x.

Güngör, D. and Bornstein, M.H. (2009). Gender, development, values, adaptation, and discrimination in acculturating adolescents: The case of Turk heritage youth born and living in Belgium. Sex Roles 60: 537-548. doi:10.1007/s11199-0089531-2. 
Harris, A.C. (1994). Ethnicity as a determinant of sex role identity: A replication study of item selection for the Bem Sex Role Inventory. Sex Roles 31(3-4): 241-273. doi:10.1007/BF01547717.

Haug, S. (2008). Migration networks and migration decision-making. Journal of Ethnic and Migration Studies 34(4): 585-605. doi:10.1080/13691830801961605.

Heath, A.F., Rothon, C., and Kilpi, E. (2008). The second generation in Western Europe: Education, unemployment, and occupational attainment. Annual Review of Sociology 34(1): 211-235. doi:10.1146/annurev.soc.34.040507.134728.

Hooper, D., Coughlan, J., and Mullen, M.R. (2008). Structural equation modelling: Guidelines for determining model fit. The Electronic Journal of Business Research Methods 6: 53-60.

Hornstra, N., Groenewold, W., and Lessard-Phillips, L. (2012). The Turkish and Moroccan second generation and their comparison group peers in Amsterdam and Rotterdam: Technical report and codebook of the TIES (The integration of the European second generation) 2006-2007 project surveys. Amsterdam: DANS/Pallas Publications, Amsterdam University Press (DANS Data Guide 9).

Huschek, D., de Valk, H.A.G., and Liefbroer, A.C. (2012). Partner choice patterns among the descendants of Turkish immigrants in Europe. European Journal of Population 28(3): 241-268. doi:10.1007/s10680-012-9265-2.

Idema, H. and Phalet, K. (2007). Transmission of gender-role values in TurkishGerman migrant families: The role of gender, intergenerational and intercultural relations. Zeitschrift Für Familienforschung: Journal of Family Research 19(1): 71-105.

Kenny, D.A. (2014). Measuring model fit [electronic resource]. http://davidakenny.net/ $\mathrm{cm} /$ fit.htm.

Kenny, D.A. (2017). MedPower (Power and N computations for mediation) [electronic resource]. https://davidakenny.shinyapps.io/MedPower/.

King, R. and Kilinc, N. (2013). Euro-Turks' return: The counterdiasporic migration of German-born Turks to Turkey. Malmö: Institute for Studies of Migration, Diversity and Welfare (Willy Brandt Series of Working Papers in International Migration and Ethnic Relations, 2/13).

Kline, R.B. (2011). Principles and practice of structural equation modeling. New York: Guilford Press. 
Levitt, P. (2009). Roots and routes: Understanding the lives of the second generation transnationally. Journal of Ethnic and Migration Studies 35(7): 1225-1242. doi:10.1080/13691830903006309.

Levitt, P. and Jaworsky, B.N. (2007). Transnational migration studies: Past developments and future trends. Annual Review of Sociology 33(7): 129-156. doi:10.1146/annurev.soc.33.040406.131816.

Lin, I.F. and Schaeffer, N.C. (1995). Using survey participants to estimate the impact of nonparticipation. Public Opinion Quarterly 59(2): 236-258. doi:10.1086/ 269471.

Linting, M., Meulman, J.J., Groenen, P.J.F., and Van der Kooij, A.J. (2007). Nonlinear principal components analysis: Introduction and application. Psychological Methods 12(3): 336-358. doi:10.1037/1082-989X.12.3.336.

Luszczynska, A., Gutierrez-Dona, B., and Schwarzer, R. (2005). General self-efficacy in various domains of human functioning: Evidence from five countries. International Journal of Psychology 40(2): 80-89. doi:10.1080/ 00207590444000041.

Massey, D.S., Arango, J., Hugo, G., Kouaouci, A., Pellegrino, A., and Taylor, J.E. (1999). Worlds in motion: Understanding international migration at the end of the millennium. Oxford: Clarendon Press.

McIver, J.P. and Carmines, E.G. (1981). Uni-dimensional scaling: Quantitative applications in the social sciences. London: Sage. doi:10.4135/ 9781412986441.

Nahapiet, J. and Ghoshal, S. (1998). Social capital, intellectual capital, and the organizational advantage. Academy of Management Review 23(2): 242-266.

Navas, M., Rojas, A.J., Garcia, M., and Pumares, P. (2007). Acculturation strategies and attitudes according to the Relative Acculturation Extended Model (RAEM): The perspectives of natives versus immigrants. International Journal of Intercultural Relations 31(1): 67-86. doi:10.1016/j.ijintrel.2006.08.002.

Pew Research Center (2005). An uncertain road: Muslims and the future of Europe. [electronic resource]. Washington, D.C.: Pew Research Center. http://www. pewforum.org/2005/10/19/an-uncertain-road-muslims-and-the-future-of-europe/.

Portes, A. and Rumbaut, R. (2001). Legacies: The story of the immigrant second generation. Berkeley: University of California Press. 
Schiller, N.G., Basch, L., and Blanc-Szanton, C. (1992). Transnationalism: A new analytic framework for understanding migration. Annals of the New York Academy of Sciences 645(1): 1-24. doi:10.1111/j.1749-6632.1992.tb33484.x.

Schwarzer, R. and Jerusalem, M. (1995). Generalized self-efficacy scale. In: Johnston, M., Weinman, J., and Wright, S. (eds.). Measures in health psychology: A user's portfolio. Windsor: NFER: 35-37.

Snel, E., Engbersen, G., and Leerkes, A. (2006). Transnational involvement and social integration. Global Networks 6(3): 285-308. doi:10.1111/j.1471-0374.2006. 00145.x.

Soper, D.S. (2017). Post-hoc statistical power calculator for multiple regression [electronic source]. http://www.danielsoper.com/statcalc.

Stoop, I.A.L. (2005). The hunt for the last respondent: Nonresponse in sample surveys [PhD thesis]. Utrecht: Utrecht University, Department of Social Sciences.

Vedder, P., Sam, D.L., and Liebkind, K. (2007). The acculturation and adaptation of Turkish adolescents in North-Western Europe. Applied Development Science 11(3): 126-136. doi:10.1080/10888690701454617.

Wessendorf, S. (2013). Second-generation transnationalism and roots migration: Cross-border lives. Farnham: Ashgate.

Westin, C. (2003). Young people of migrant origin in Sweden. International Migration Review 37(4): 987-1010. doi:10.1111/j.1747-7379.2003.tb00167.x. 
Groenewold \& de Valk: Acculturation style, transnational behaviour, and return-migration intentions 